\title{
Prototype of Web System for Organizations Dedicated to e-Commerce under the SCRUM Methodology
}

\author{
Ventocilla Gomero-Fanny ${ }^{1}$, Aguila Ruiz Bengy ${ }^{2}$, Laberiano Andrade-Arenas ${ }^{3}$ \\ Facultad de Ciencias e Ingeniería, Universidad de Ciencias y Humanidades, Lima, Perú
}

\begin{abstract}
This research work is based on making a prototype e-commerce system applying the scrum methodology, because currently the systems of many organizations are still developed following traditional methodologies, i.e. the system does not meet the requirements that should provide value to the organization in addition to its poor information security, leading to the organization's data to the vulnerability of loss or theft. That is why this article aims to design a web system for organizations dedicated to e-commerce under the agile SCRUM methodology. The methodology allowed to design the prototype meeting the needs of the organization with frequent retrospectives and continuous communication between stakeholders, in addition to proposing the information security of the company's data. In the results of this research the user stories were analyzed, which allowed the division into 4 Sprint deliverables of the general modules proposed in the article, for which a maximum score of 21 story points per Sprint was placed; in which 16 story points were placed to the first sprint, the second Sprint with 20 story points, the third Sprint with 21 story points and the fourth Sprint with 16 story points. The e-commerce system proposal will be beneficial for the organization and its customers, since it will allow them to have a system according to their requirements and needs in a secure manner.
\end{abstract} sprint

Keywords-Agile; e-commerce; scrum; sales; user stories;

\section{INTRODUCTION}

Nowadays, e-commerce is a very important phenomenon that contributes to the technological development of organizations all over the world, since the use of technology has become a transcendental issue in the daily life of a company, because through the use of cell phones it allows a close relationship between the processes of the organizations, then knowing the importance that marks in our days the electronic commerce is necessary to know the concept of it, which is defined as the transaction that is made or produced through the Internet, as the commercial transactions implies the exchange of value across the borders of the companies or individuals in exchange for service or products that are required [1].

In Peru, the use of e-commerce in organizations is becoming increasingly important due to the new era of trade through the Internet [2]. Since the Internet has become part of the lives of the vast majority of citizens, due to reduced costs has been possible to reach many more people, so that organizations both in Peru and in the world, takes advantage of customer connectivity to a network, being born there the desire to improve the business through the Internet through digital marketing, advertising and others that make possible the mass segmentation of its customers, this is what gives rise to ecommerce order companies dedicated to trade [3].

Also in another research, published by Yadong Huang, Yi Liu, Jianping Shen titled as architecture of next generation ecommerce platform, mentions that, e-commerce has significantly changed the rules in business as they have made e-commerce more intelligent and convenient to perform transactions of all kinds [4]. Also Nayoung Hong, Junbeom Yoo, Sungdeok Cha, mention in their research on customization of Scrum methodology for e-commerce projects, where they analyzed their research by dividing the scrum method into three aspects and showed results of surveys conducted on satisfaction of using scrum methodology components to 18 members where they indicate that $17 \%$ are very satisfied, $66 \%$ satisfied and $17 \%$ indicate that nothing special in using the methodology. Then analyzing the data, we can mention that scrum is a methodology quite used and comfortable for the development of e-commerce projects [5].

The objective of this work is to design a web system for organizations dedicated to e-commerce under the SCRUM methodology.

In the article, in Section II, the literature review of the research is shown, in Section III, the methodology established, in Section IV, the case study of the research, in Section V, the results and discussions reached with the present and finally in Section VI, the conclusions and future work are shown.

\section{LITERATURE REVIEW}

In addition in another research, published by Yadong Huang, Yi Liu, Jianping Shen In this section are shown important aspects to be addressed, which are related to ecommerce as E-Business, digital marketing, ISO 27001-Annex A9 (as a security issue and information risk prevention for companies and their customers), also clear concepts about scrum the methodology applied in the research and in addition to proposals for development tools for the implementation of the prototype presented.

Then, e-business is understood as the economic activity and business management practices that are carried out through the Internet, in addition to that you can find content editions of images and titles, discussion forums, which make a website 
interactive and the user can share ideas and opinions about the products offered; and in addition to providing the advantage of updating and rebuilding a website more easily, exploiting online information, increasing transparency and quality of processes [6].

Digital marketing is understood as the traditional marketing techniques in the digital environment [7]. As for ISO 27001, it is also timely to mention it because it aims to enable organizations to prioritize controls based on their possibility and necessity, i.e., risks in an organization's system, which must be analyzed and managed, and security must be planned, implemented and especially when reviewed must be corrected and improved [8], specifically Annex A9 of ISO 27001, seeks to safeguard the organization's assets, as it could be breached by unscrupulous users with access to an organization's system without any limitation whether it is an internal or external user [9]. Information security in an organization is and will remain the most important asset as this asset could seriously affect a company and even bankrupt a well-positioned organization [10].

Regarding the methodology, SCRUM was used, being one of the most used methodologies in the agile environment that allows continuous communication between stakeholders, so that errors in software delivery are minimized, thanks to frequent sprints and where changes in requirements are also welcomed during the project development [11]. Besides being organized by roles such as the Scrum Master, the development team and the Product Owner, which make possible the development of the system in an agile environment. Then for the development of this research will follow the processes, phases and principles established by the agile methodology SCRUM [12].

For the development of the e-commerce system, it is proposed to be developed in PHP in a development environment such as Visual studio code [13], with the MySQL server database and using the Laravel 7 framework [14].

\section{METHODOLOGY}

As it has been mentioned above, the methodology that will be applied in this article is the SCRUM agile methodology, due to its agile environment that will allow those involved to interact continuously through the sprint, and then the agile develop [15].

\section{A. Startup Stage}

In this phase of the agile methodology, those involved in the research will be described, i.e. the formation of the SCRUM group, the user stories approved by the Product Owner will be described.

\section{B. Planning}

Identify applicable sponsor/s here. If no sponsors, delete this text box (sponsors). In this phase we will list the creation of the horses, tasks and requirements which will be estimated by size, following the development we will make a story and user map with the specification of your Product Roadmap [16]. A chart is also made with the planning of the Sprint as well as the determination of the costs or budgets that will be necessary for the implementation.

\section{Implementation}

In this phase the prototypes of the e-commerce system will be developed, by modules according to the established user stories, prioritized and estimated during planning.

\section{Review and Retrospective}

In this phase the Sprint is validated, if it is really complying with the established if a change is necessary.

\section{E. Feedback}

In this meeting, plans were made and created to improve the execution of the following Sprint, evaluating the development of the feedback given in the previous meetings of the development team.

\section{CASE STUdy}

In this section, we will develop the proposed methodology, where in each of the SCRUM phase we will detail the case study applied to carry out the correct development of the agile methodology in this study, with which to provide a proposal for the development of the interactive and feasible e-commerce system that provides value to organizations engaged in trade. To do so, we first show the flowchart of the proposed system in Fig. 1, for a better understanding of the system.

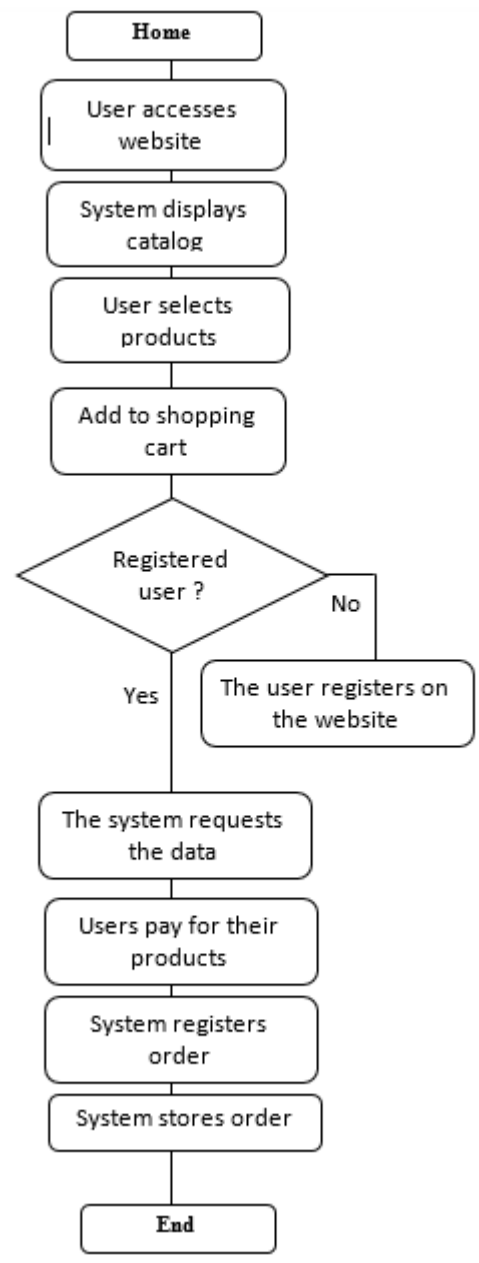

Fig. 1. System Operating Flow. 


\section{A. Startup Stage}

1) Identification of those involved: We mention the people who will be involved in the process of developing the ecommerce system, which in turn will be in constant communication, according to the established in the Scrum methodologies as shown in the following Table I.

2) Description and prioritization of user stories: The people who will be involved in the process of developing the e-commerce system are mentioned, (P.1 is developer 01, and P.2 is developer 02) who in turn will be in constant communication, as established in the Scrum methodologies as shown in Table II.

\section{B. Planning Stage}

1) Decomposition of epics to tasks: In the following one it is shown to decompose the hepicas to simpler tasks to make, as it is observed in Table III.

TABLE I. INVOLVED

\begin{tabular}{|l|l|}
\hline ROLE & DESCRIPTION \\
\hline Product Owner & System owner \\
\hline Scrum Master & Project members \\
\hline Development Team & Project members \\
\hline
\end{tabular}

TABLE II. USER STORIES WITH PRIORITY

\section{USER HISTORY}

As the owner of the organization, I want the system to allow a user role, to have a better access control to the modules.

I, as a salesperson of the organization, want the system to be able to divide by category all the products, to have a better control of the stock and to carry out the sales in a more efficient way.

I as the Purchasing Manager of the organization require that the system can have a product registration option, in order to maintain stock control of the product.

As the organization's distribution manager, I require the system to have ubigeo records for each customer, in order to better serve their orders and generate sectorized promotions.

I, as the organization's vendor, require that the system be able to record my order in a timely and detailed manner, for time efficient service.

As the organization's purchasing manager, I want the system to be able to record my purchases in detail, in order to have better control of purchases and suppliers

As the owner of the organization, I want the system to be able to provide me with reports, by day, month and year, to have a better control of it.

I, as the owner of the organization, want the system to be able to give me configuration access, so that I can manage it as I see fit.

I, as the owner of the organization, want the system to be able to have a Deshboard area, that is, a report of the most sold and most required products.

As a salesperson for the organization, I want the system to be able to have a sales catalog, to have a better overview of the products.

As a sales manager, I require the system to detail the products, to have the specific description of each product.

As the owner of the organization, I want the system to be able to record the profile of each of our clients, for decision-making purposes.

I as an owner require that the system can show me the report of each customer, to have a purchase history of the customers

\begin{tabular}{|l|l|l|l|l|}
\hline $\mathbf{N}^{\mathbf{0}}$ & $\mathbf{P . 1}$ & $\mathbf{P . 2}$ & Priority \\
\hline 1 & 13 & 13 & 8 \\
\hline 2 & 13 & 13 & 8 \\
\hline 3 & 8 & 8 & 8 \\
\hline 4 & 8 & 8 & 8 \\
\hline 5 & 5 & 5 & 5 \\
\hline 6 & 5 & 5 & 5 \\
\hline 7 & 5 & 5 & 5 \\
\hline 8 & 5 & 5 & 5 \\
\hline 9 & 3 & 3 & 3 \\
\hline 10 & 3 & 3 & 3 \\
\hline 11 & 3 & 3 & 3 \\
\hline 12 & 1 & 1 & 3 \\
\hline 13 & 1 & 1 & 3 \\
\hline
\end{tabular}

TABLE III. EPIC DECOMPOSITION

\begin{tabular}{|c|c|}
\hline REQUIREMENTS & TASKS \\
\hline Role of users & $\begin{array}{l}\text { Add user } \\
\text { Delete user } \\
\text { Modify user data } \\
\text { Save user } \\
\end{array}$ \\
\hline Product Category & Add category, delete category, modify category, save category \\
\hline Product Registration & Add product, remove product, modify product, save product \\
\hline Ubiquitous registration & Modify ubigeo, delete ubigeo, save ubigeo \\
\hline Order registration & $\begin{array}{l}\text { Consult Product, Add New Product } \\
\text { Cancel Sale } \\
\text { Modify Product }\end{array}$ \\
\hline Purchase record & $\begin{array}{l}\text { Register supplier data } \\
\text { Register products to buy } \\
\text { Cancel purchase, Add new product } \\
\text { Make a purchase }\end{array}$ \\
\hline Report Registration & $\begin{array}{l}\text { Show sales record for day ,month and year } \\
\text { Show Stock } \\
\text { Generate Commission Reports } \\
\text { Report by Seller }\end{array}$ \\
\hline Configuration access & Edit configuration area \\
\hline Deshboard Registration & Add product, remove product, modify product, save product \\
\hline Product catalog & Add, remove, modify and display product in catalog list \\
\hline Product detail & Show detail \\
\hline Customer Profile Registration & $\begin{array}{l}\text { Add client } \\
\text { Delete customer } \\
\text { Modify customer data } \\
\text { Save client }\end{array}$ \\
\hline Customer Report & Show report \\
\hline
\end{tabular}


2) Backlog estimation: In the next one we will estimate the usury stories using the size estimation, which will allow the requirements to be separated by sprints according to the story points assigned in the estimation as shown in Fig. 2. This was done with the members of the project development and these results were obtained, where we can visualize that 73 points of user history were obtained.

3) User story map with product roadmap: In Table IV you can see the map of user history, in addition to the roadmap of products ie the path to be followed for compliance with the sprinst, the top is the most required being the Backbone, followed by the Walkin Skeleton, ie the modules required by the system to operate.

4) Plamification of deliverables (Sprints): The 73 story points observed in the estimation by sizes shown in Table $\mathrm{V}$ are then shown. These are broken down by a range of less than 21 story points, to ensure the security of your information.

\section{Implementation Stage}

In this phase, the prototype of the e-commerce System will be designed following the established requirements and will be designed by Sprint as the first version, since they could vary through the retrospective with the Owner products, since in Scrum the changes are welcome.

1) Initial prototype : The prototypes were planned based on the requirements previously analyzed and ordered.

a) Prototype of Sprint 1: For the development of the first prototype, the decomposition of epics from Table III and Table V of Sprint planning 1 were taken into account, as shown in Fig. 3, Fig. 4 and Fig. 5.

b) Prototype of Sprint 2: For the development of the second prototype, the decomposition of epics from Table III and the Sprint 2 planning Table $\mathrm{V}$ were taken into account, as shown in Fig. 6, Fig. 7, and Fig. 8.

c) Initial Prototype of Sprint 3: For the development of the third prototype the decomposition of epics from Table III and the planning Table $\mathrm{V}$ of Sprint 3 were taken into account, therefore in Fig. 9 one of the most important prototypes of this sprint 3 can be seen.

d) Initial Prototype of Sprint 4: For the development of the fourth prototype the decomposition of epics from Table III and the planning Table V of Sprint 4 were taken into account, therefore in Fig. 10 one of the most important prototypes of this sprint 10 can be seen.

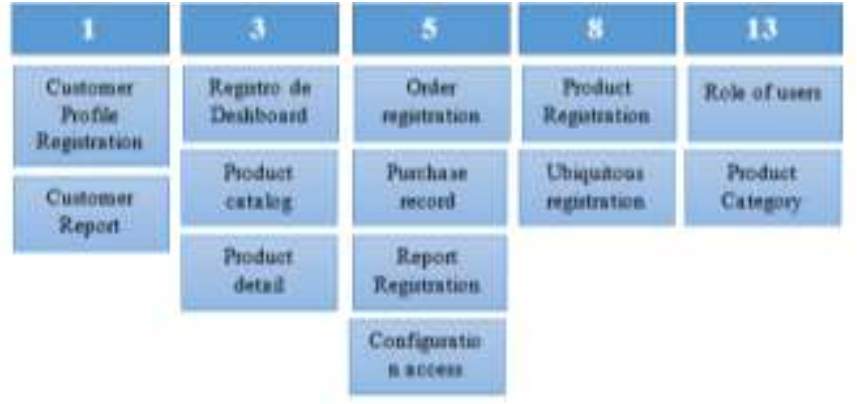

TABLE IV. PRODUCT ROADMAP

\begin{tabular}{|l|l|l|l|l|}
\hline & $\begin{array}{l}\text { register } \\
\text { products }\end{array}$ & selling & $\begin{array}{l}\text { generate } \\
\text { reports }\end{array}$ & $\begin{array}{l}\text { register } \\
\text { users }\end{array}$ \\
\hline Backbone & $\begin{array}{l}\text { Product } \\
\text { Registration }\end{array}$ & $\begin{array}{l}\text { Product } \\
\text { catalog }\end{array}$ & $\begin{array}{l}\text { Record } \\
\text { Report }\end{array}$ & $\begin{array}{l}\text { Role of } \\
\text { users }\end{array}$ \\
\hline $\begin{array}{l}\text { Walking } \\
\text { Skeleton }\end{array}$ & $\begin{array}{l}\text { Purchase } \\
\text { registration }\end{array}$ & $\begin{array}{l}\text { Order } \\
\text { registration }\end{array}$ & & \\
\hline $\begin{array}{l}\text { Less } \\
\text { Optional }\end{array}$ & Product detail & $\begin{array}{l}\text { Product } \\
\text { Category }\end{array}$ & & $\begin{array}{l}\text { Customer } \\
\text { Profile } \\
\text { Registration }\end{array}$ \\
\hline & & $\begin{array}{l}\text { Customer } \\
\text { Report }\end{array}$ & \\
\hline $\begin{array}{l}\text { Optionalit } \\
\mathbf{y}\end{array}$ & $\begin{array}{l}\text { Dashboard } \\
\text { Registration }\end{array}$ & $\begin{array}{l}\text { Ubiquitous } \\
\text { registration }\end{array}$ & & \\
\hline $\begin{array}{l}\text { More } \\
\text { Optional }\end{array}$ & & & & \\
\hline
\end{tabular}

TABLE V. PLANNING OF SPRINTS

\begin{tabular}{|c|c|c|c|}
\hline $\mathrm{N}^{\circ}$ de Sprint & Description & Value & Sprint points \\
\hline \multirow{3}{*}{1} & Record Report & 5 & \multirow{3}{*}{16 points } \\
\hline & Product catalog & 3 & \\
\hline & Product Registration & 8 & \\
\hline \multirow{4}{*}{2} & Users' role & 13 & \multirow{4}{*}{20 points } \\
\hline & Purchase registration & 5 & \\
\hline & Customer Profile Registration & 1 & \\
\hline & Customer Report & 1 & \\
\hline \multirow{3}{*}{3} & Order registration & 5 & \multirow{3}{*}{21 points } \\
\hline & Product detail & 3 & \\
\hline & Product Category & 13 & \\
\hline \multirow{3}{*}{4} & Configuration access & 5 & \multirow{3}{*}{16 points } \\
\hline & Ubiquitous registration & 8 & \\
\hline & Deshboard Registration & 3 & \\
\hline
\end{tabular}

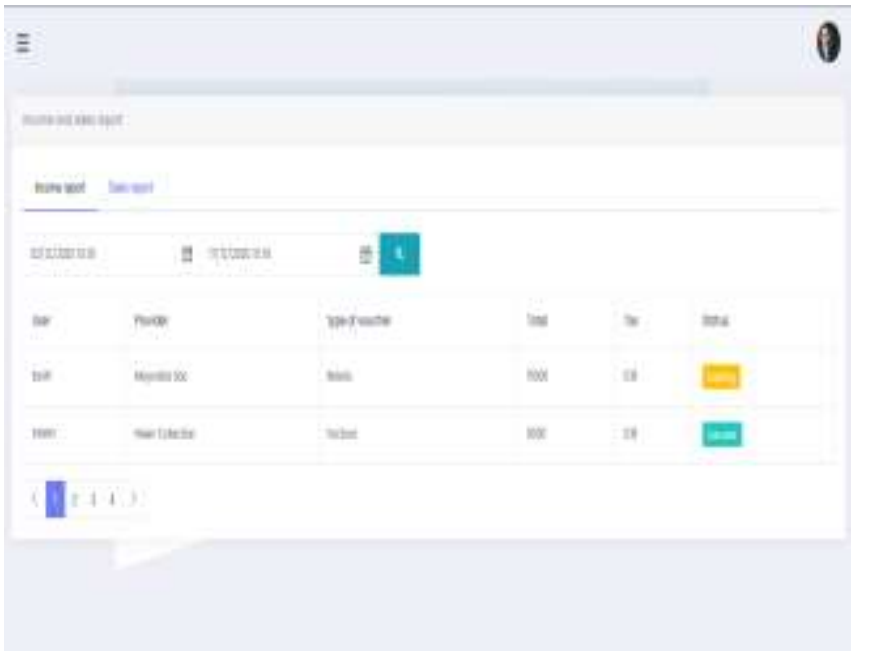

Fig. 3. Reports Module.

Fig. 2. Backlog Estimation. 

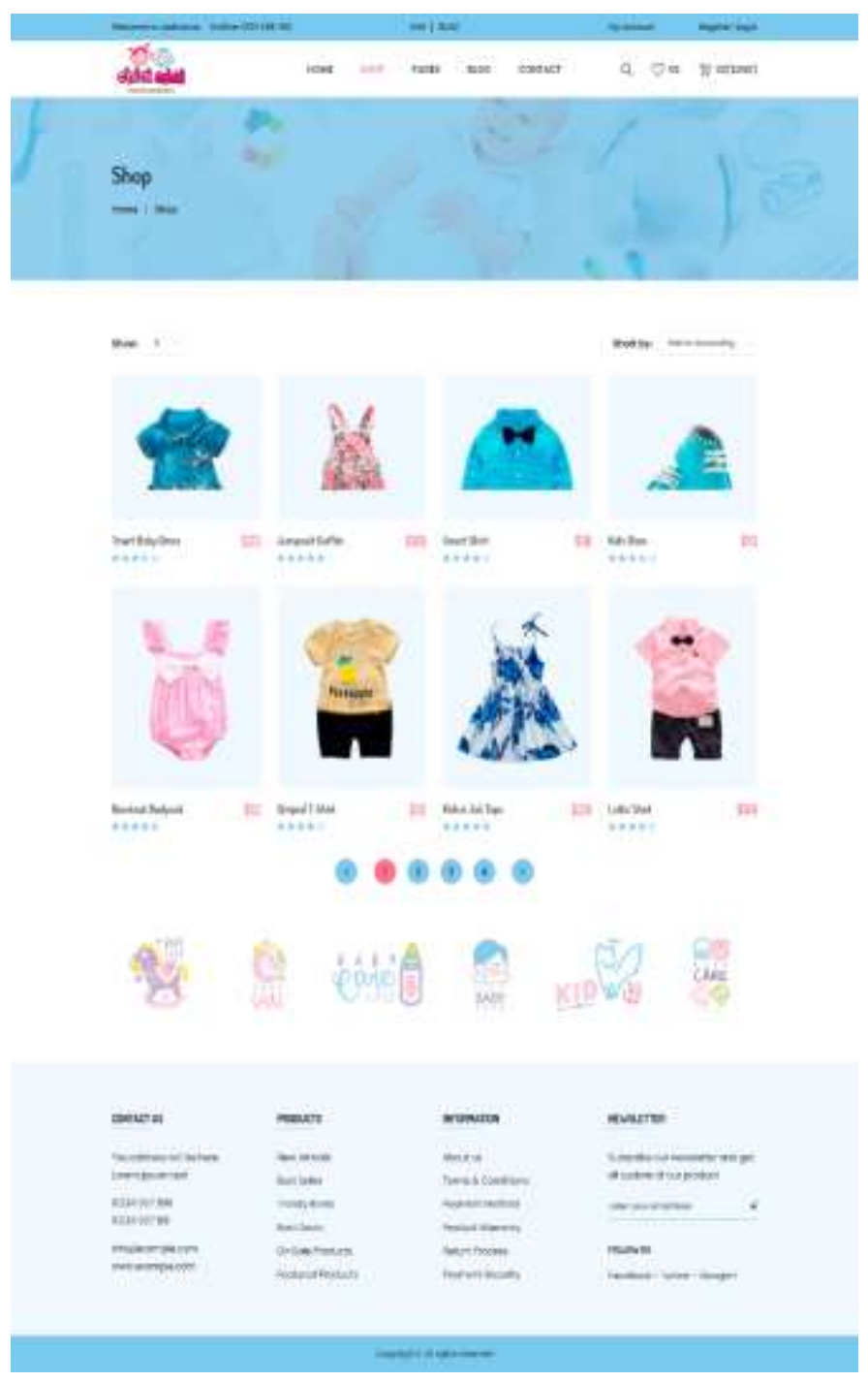

Fig. 4. Product Catalog.

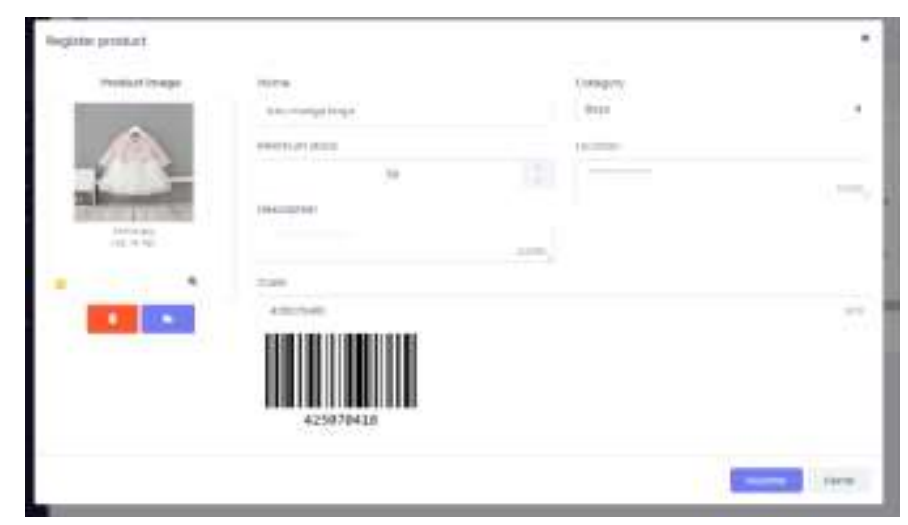

Fig. 5. Register Product.

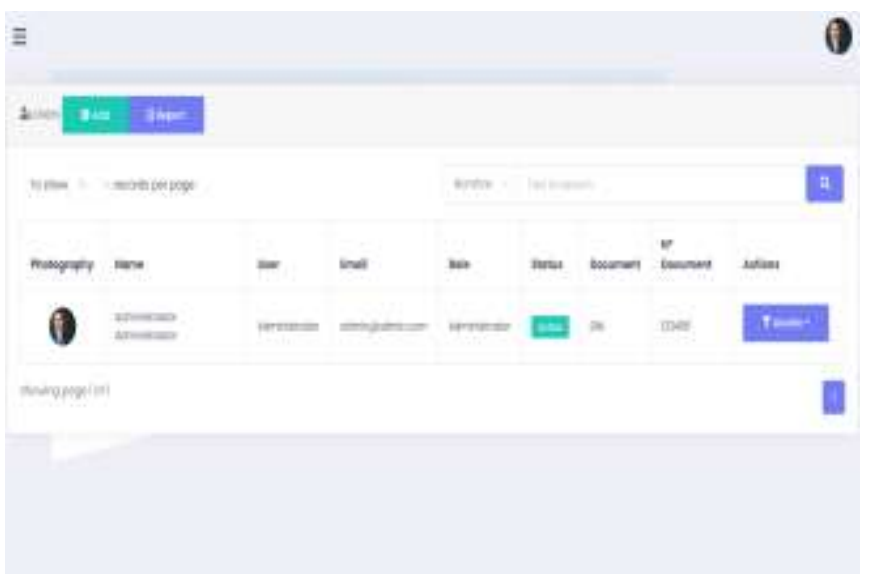

Fig. 6. User Registration.

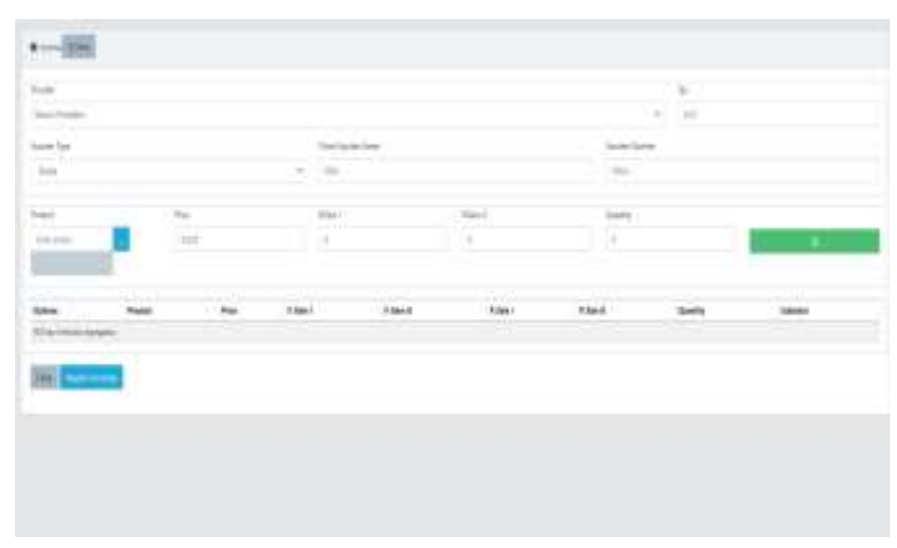

Fig. 7. Shopping Record.

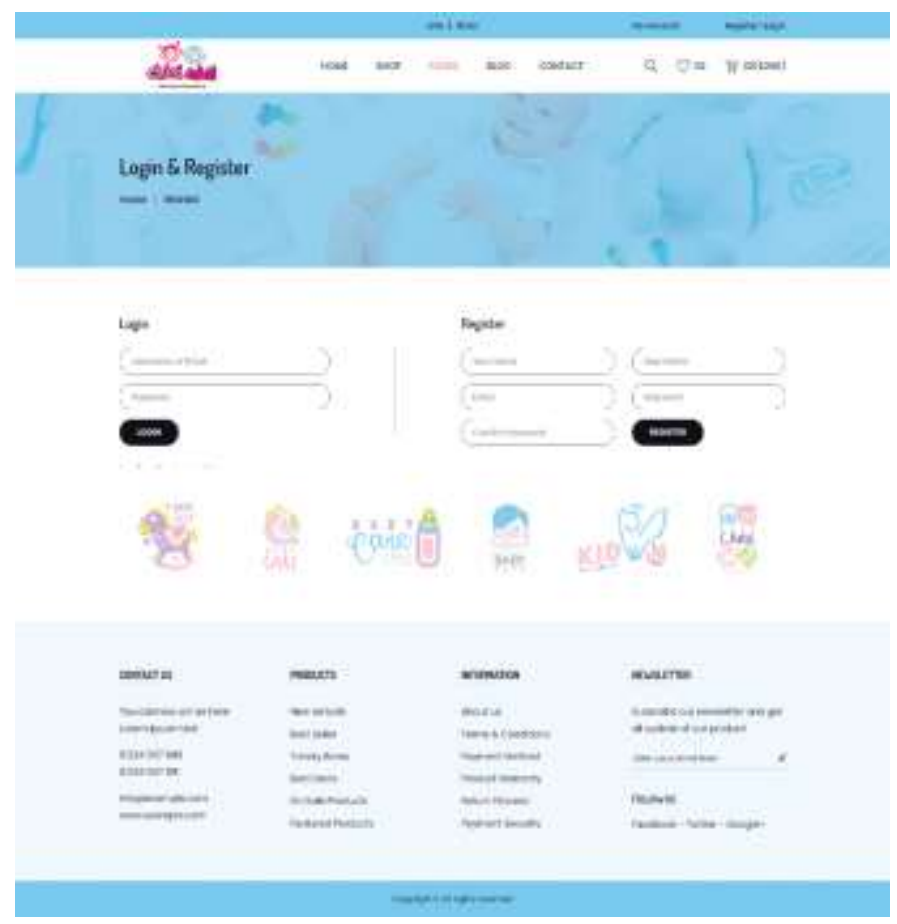

Fig. 8. Customer Profile Registration. 

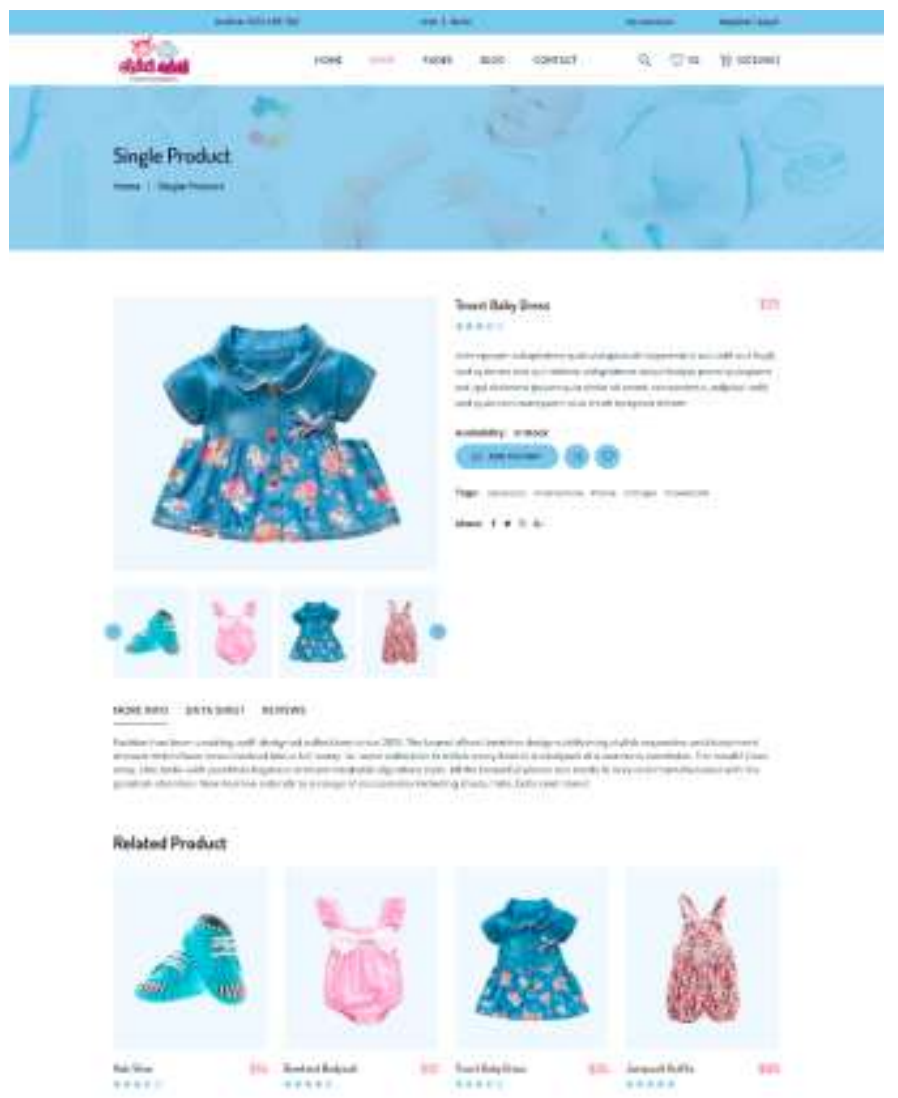

Fig. 9. Product Detail.

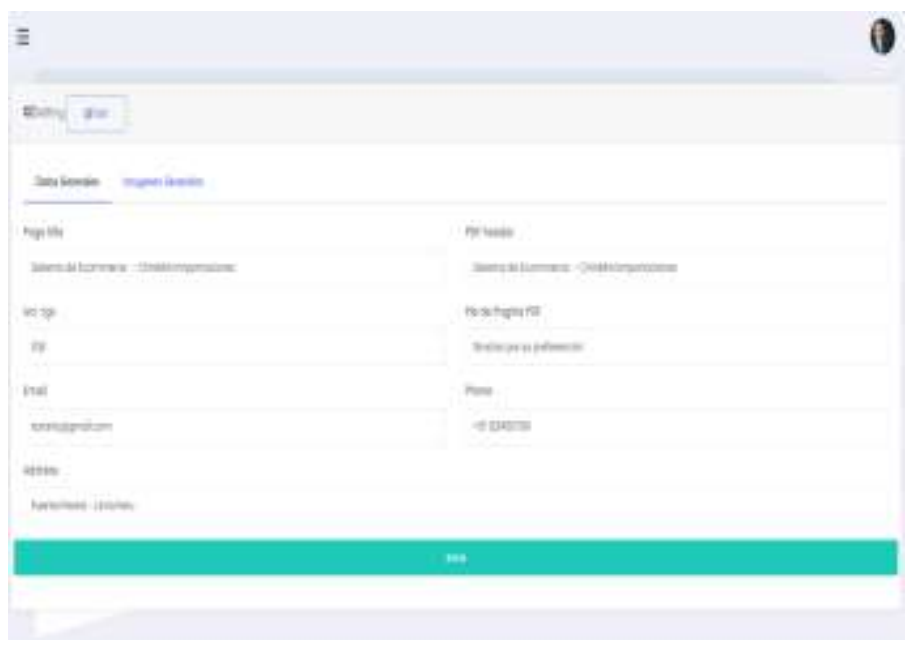

Fig. 10. Page Setup.

\section{RESULTS AND DISCUSSIONS}

It is shown the results and discussions reached in this article, in the results part it was made the detailed explanation of the operation of each one of the Sprint, and in the discussions part it was made a description of two agile methodologies such as SCRUM and XP, in order to provide the reader with the similarities and differences of these two methodologies.

\section{A. About case Study}

We analyzed the 4 Sprint of the general modules proposed in the article for which was placed as a maximum score of 21 points of history by Sprint in which the first sprint has 16 points of history, the second Sprint with 20 points of history, the third Sprint with 21 points of history and the fourth Sprint with 16 points of history. These in turn have a number of 3 to 4 modules according to the score or value evidenced, obviously following (see Table V) the path of the Product Roadmap, where the yellow color represents Backbone, the orange color the Walking Skeleton, the green color the Less Optional and the purple color the Optional (see Table IV). Having mentioned the order of delivery of the Sprint below is to describe each module by Sprint.

1) For Spirnt 1: It is delivered as a prototype the report registration modules in which the general view of reports by day, month and year is detailed in an infective view; in the product catalog module the products are visualized properly detailed and interactive for the different users and in the product registration module a registration view of the products is visualized so that they are registered in detail. In Fig. 11, it is shown in the sprint 1 burst chart, the path taken by the sprint in a given time of 28 days shown in the $\mathrm{X}$ axis and in the $\mathrm{Y}$ axis the 16 points of user stories, that is the expected time with the real time of development of the sprint.

2) For Spirnt 2: In this Sprint are delivered with retrospective the prototype of the user module in which it is observed in detail the different users who will have access to the e-commerce system with certain limitations by type of user, in the module of registration of purchases are observed the very detailed prototype in which it will be possible to register the purchases made for the correct control of stock, in the module of client profile is observed the record of the clients to be categorized later and in the module client report, the clients already registered in the system are visualized. In the Fig. 12, it is observed in the sprint 2 burdow chart, the expected advance of the sprint development and the real way that was taken for the development of the same one, in a time of 28 days as it is shown in the $\mathrm{X}$ axis, and in the $\mathrm{Y}$ axis the 20 points of history.

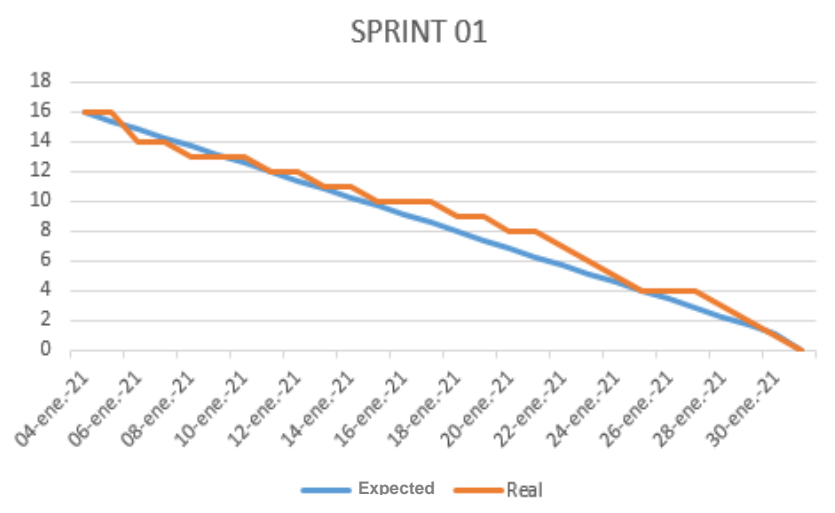

Fig. 11. Development Path for Sprint 1. 


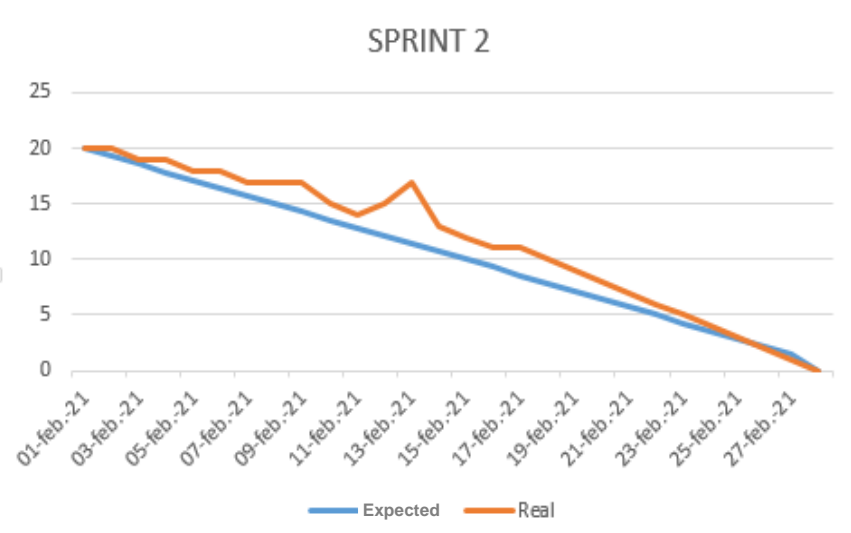

Fig. 12. Development Path for Sprint 2.

3) For Spirnt 3: The deliverables in this sprint are the prototype of the order registration module which details the registration of orders placed by customers, in the product detail module displays the product more detailed than in the catalog due to the description of each product, in the product category module displays the types of product categorized by texture, shape or others that differentiate them. In Fig. 13, the path taken by the sprint during its development stage is shown in a time of 31 days shown in the $\mathrm{Y}$ axis, for its feedback, with 21 points of user history shown in the $\mathrm{X}$ axis.

4) For Spirnt 4: The deliverables in this sprint are the configuration access that is a restricted module only for the user administrator of the e-commerce system, in the registration module of ubigeo are recorded the address by province, district and department of users and addressing of the stores of the organization, and finally in the registration module of Deshboard are the general reports of all made in statistical form for senior management decisions. In Fig. 14, it is shown in the same way the path that the sprint took in its development stage in a period of 16 working days shown in the $\mathrm{Y}$ axis, with 16 points of history shown in the $\mathrm{x}$-axis.

\section{B. About Methodology}

Scrum and XP (Extreme Programming) are two methodologies of software development very used, the differences between both are firstly in the time of the deliverables or also called sprints or interactions because in scrum a sprint can take between a week and a month, in the course of the development this sprint cannot receive changes ie is not sensitive to changes at least until the sprint has been completed, on the other hand, the time it takes an interaction in $\mathrm{XP}$ is one to two weeks, in this methodology changes are welcome i.e. is sensitive to changes, may have concluded some interactions [17], these will be open to change, in scrum the order of priorities are established by the Product owner instead in XP establishes the customer, another very noticeable and important comparison is that Scrum is based on the management of a project, on the other hand XP is focused clearly on the realization of the product [18], while it is true that both methodologies are very good, our project was developed based on the agile methodology of software development scrum for project management, in addition to the order of priorities we establish based on customer requirements. In the Table VI, we show the sales and disadvantages of these two methodologies compared.

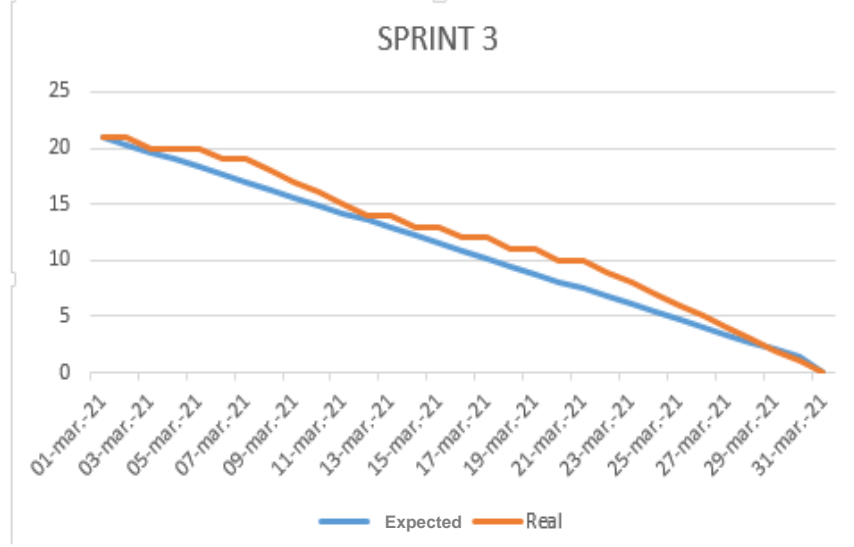

Fig. 13. Development Path for Sprint 3.

\section{SPRINT 4}

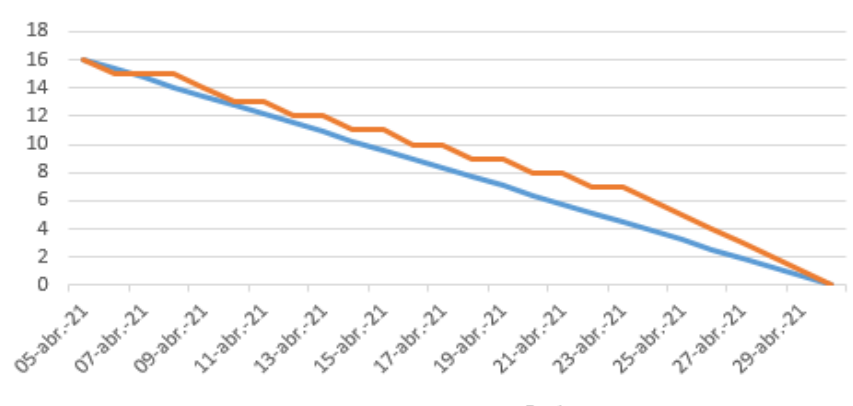

Fig. 14. Development Path for Sprint 4.

TABLE VI. COMPARISON BETWEEN SCRUM AND XP

\begin{tabular}{|c|c|c|}
\hline & Extreme Programming (XP) & Scrum \\
\hline 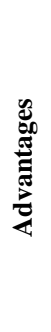 & $\begin{array}{l}\text { 1.- More organized } \\
\text { programming. } \\
\text { 2.- Continuous improvement of } \\
\text { processes and development } \\
\text { teams. } \\
\text { 3.- Increased communication } \\
\text { between clients and development } \\
\text { team. } \\
\text { 4.- Less error. }\end{array}$ & $\begin{array}{l}\text { 1.- Anticipated results } \\
\text { 2.- Flexibility and adaptation of } \\
\text { context } \\
\text { 3.- Risk management. } \\
\text { 5.- shows the progress of the } \\
\text { sprints or deliverables. } \\
\text { 6.- S e obtains fast results and } \\
\text { very short test periods. } \\
\text { 7.- Shows a complete vision of } \\
\text { the project. }\end{array}$ \\
\hline 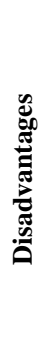 & $\begin{array}{l}\text { 1.- It is a little difficult to } \\
\text { document. } \\
\text { 2.- It is recommended to use only } \\
\text { in short projects. } \\
\text { 3.- if a process there, the costs } \\
\text { are high. }\end{array}$ & $\begin{array}{l}\text { 1.- It works more in reduced } \\
\text { equipment. } \\
\text { 2.- It requires an exhaustive } \\
\text { definition of the tasks and their } \\
\text { deadlines. } \\
\text { 3.- if there are unfinished tasks, } \\
\text { the rest of the tasks have to be } \\
\text { postponed. } \\
\text { 4.- Daily meetings can create } \\
\text { stress and frustration among less } \\
\text { experienced members }\end{array}$ \\
\hline
\end{tabular}




\section{CONCLUSIONS AND FUTURE WORK}

In conclusion, the e-commerce systems developed with the agile methodology SCRUM, allowed the system to be based more on the fulfillment of the requirements of the customers, so that it was better adapted to the organization and its needs since the changes in the requirements were welcomed in the agile environment worked, in addition the continuous communication between the stakeholders have made possible the estimation and prioritization of the user stories studied and also gave a path of development in the Product Roadmap to finally be separated by sprint as deliverables. The sprints were separated into 4 deliverables which will be proposed for delivery in a period of 1 to 2 weeks, according to the score of user stories considered in each of the sprints.

It is recommended to further investigate so that sprints can be made with fewer story points, to further detail the requirements and also to implement the e-commerce system in the future with the analysis of the requirements presented in this article.

\section{REFERENCES}

[1] R. Villegas, «La implementación del e-commerce en Flore,» El Capiro SA, Colombia, 2020.

[2] D. A. Navarro, B. V. D. Lucca y E. V. Gonzabay, «E-Commerce: Un Factor Fundamental Para El Desarrollo Empresarial En El Ecuador,» Revista Cientifica Ecociencia, p. 17, 2018.

[3] Q. Wu, J. Ma and Z. Wu, "Consumer-Driven E-Commerce: A Study on C2B Applications," 2020 International Conference on E-Commerce and Internet Technology (ECIT), Zhangjiajie, China, 2020, pp. 50-53, doi: 10.1109/ECIT50008.2020.00019.

[4] Y. Huang, Y. Chai, Y. Liu y J. Shen, "Arquitectura de la plataforma de comercio electrónico de próxima generación", en Tsinghua Science and Technology, vol. 24, no. 1, págs. 18-29, febrero de 2019, doi: 10.26599 / TST.2018.9010067.

[5] N. Hong, J. Yoo y S. Cha, "Personalización de la metodología Scrum para proyectos de comercio electrónico subcontratados" , Conferencia de ingeniería de software de Asia Pacífico 2010 , Sydney, NSW, 2010, págs. 310-315, doi: 10.1109 / APSEC. 2010.43.

[6] P. Restrepo, « The implementation of E-Commerce in Flores El Capiro, » College of Higher Studies in Administration-CESA, p. 62, 2020.
[7] C. Y. Yoon, "Measurement systems of individual E-business competency in an E-business management environment," 2017 4th International Conference on Computer Applications and Information Processing Technology (CAIPT), Kuta Bali, 2017, pp. 1-4, doi: 10.1109/CAIPT.2017.8320720.

[8] PJMAJ Malar, "Tendencias innovadoras de marketing digital 2016", Conferencia internacional de 2016 sobre técnicas eléctricas, electrónicas y de optimización (ICEEOT), Chennai, 2016, págs. 4882-4888, doi: 10.1109 / ICEEOT.2016.7755648.

[9] O. F. Mamani y T. G. Málaga, «Evaluación De Madurez De Las Tics Según La Norma Técnica Peruana Ntp-Iso/27001 -2014 En La Oficina De Informática Y Sistemas De La Unjbg, 2016,» Universidad Nacional Jorge Basadre Grohmann, Tacna - Perú, 2016.

[10] A. P. DAZA, «Diseño De Procedimientos De Gestión De Usuarios Y Gestión Del Cambio En El Sistema Kactus-Hr Aplicando Iso 27001,» Universidad Distrital "Francisco Jose De Caldas", Bogota, 2019.

[11] P. R. Gómez y G. E. Moraleda, Approach to software engineering, Editorial Centro de Estudios Ramon Areces SA, 2020, 2020.

[12] A. Srivastava, S. Bhardwaj and S. Saraswat, "SCRUM model for agile methodology," 2017 International Conference on Computing, Communication and Automation (ICCCA), Greater Noida, 2017, pp. 864-869, doi: 10.1109/CCAA.2017.8229928.

[13] A. A. Maliavko, "The Lexical and Syntactic Analyzers of the Translator for the EI Language," 2018 XIV International Scientific-Technical Conference on Actual Problems of Electronics Instrument Engineering (APEIE), Novosibirsk, 2018, pp. 360-364, doi: 10.1109/APEIE.2018.8545874.

[14] Á. P. Gómez, J. R. Jalca, J. G. García, O. Q. Sánchez, K. M. Parrales y J. M. Merino, « Database Management Basics,» 3Ciencias, 2017.

[15] L. B. Angarita and J. A. Guapachá Hernández, "Gamified system for learning of Scrum development process," 2019 14th Iberian Conference on Information Systems and Technologies (CISTI), Coimbra, Portugal, 2019, pp. 1-6, doi: 10.23919/CISTI.2019.8760928.

[16] M. A. Korimbocus, T. Singh Towokul and S. D. Nagowah, "Scrum Meeting Tool for Knowledge Capture and Sharing," 2019 Conference on Next Generation Computing Applications (NextComp), Mauritius, 2019, pp. 1-6, doi: 10.1109/NEXTCOMP.2019.8883672.

[17] A. N. Cadavid, J. D. F. Martínez y J. M. Vélez, " Review of agile methodologies for software development,» 04 junio 2013. [En línea]. Available: https://dialnet.unirioja.es/descarga/articulo/4752083.pd.

[18] J. C. Salazar,'A. T. Casallas, J. C. Linares, A. Lozano,and Y. L. Valbuena, "Scrum versus xp: similarities and differences," Technology Research \& Academy,vol. 6, no. 2, pp. 29-37, 2018. 